\title{
Potassium silicate and calcium silicate on the resistance of soybean to Phakopsora pachyrhizi infection
}

\author{
Maria Fernanda Cruz ( $\left.{ }^{1 *}\right)$; Fabrício Ávila Rodrigues ( $\left.{ }^{2}\right)$; Ana Paula Cardoso Diniz $\left({ }^{2}\right)$; \\ Maurilio Alves Moreira (3); Everaldo Gonçalves Barros (') \\ (') Universidade Federal de Viçosa (UFV), Departamento de Biologia, 36570-000 Viçosa (MG), Brasil. \\ (2) UFV, Departamento de Fitopatologia, 36570-000 Viçosa (MG), Brasil. \\ (3) UFV, Departamento de Bioquímica e Biologia Molecular, 36570-000 Viçosa, (MG), Brasil. \\ (*) Corresponding author: mariafernandaantunesdacruz@gmail.com
}

Received: Sept. 1, 2013; Accepted: Nov. 28, 2013

\begin{abstract}
The control of Asian Soybean Rust (ASR), caused by Phakopsora pachyrhizi, has been difficult due to the aggressiveness of the pathogen and the lack of resistant cultivars. The objective of this study was to evaluate the effects of spray of potassium silicate (PS) and soil amendment with calcium silicate (CS) on soybean resistance to ASR. The PS solution was sprayed to leaves 24 hours prior to fungal inoculation while CS was amended to the soil at thirty-five days before sowing. The infection process of P. pachyrhizi was investigated by scanning electron microscopy. The uredia on leaves of plants sprayed with PS were smaller and more compact than those observed on the leaves of plants grown in soil amended with CS or in soil non-amended with CS (control treatment). On leaves of plants from the control treatment, uredia produced many urediniospores at 9 days after inoculation, and the ASR severity was 15, 8 and 9\%, respectively, for plants from control, PS and CS treatments. In conclusion, the spray of PS contributed to reduce the number of uredia per $\mathrm{cm}^{2}$ of leaf area and both PS spray and CS resulted in lower ASR symptoms.
\end{abstract}

Key words: Glycine max, biotrophic fungi, scanning electron microscopy.

\section{Silicato de potássio e silicato de cálcio na resistência da soja à infecção por Phakopsora pachyrhizi}

\section{Resumo}

O controle da Ferrugem Asiática da Soja (FAS), causado pelo fungo Phakopsora pachyrhizi, tem sido difícil devido à agressividade do patógeno e pela falta de cultivares resistentes. O objetivo deste estudo foi avaliar os efeitos da pulverização com silicato de potássio (SP) e do suprimento de Si via silicato de cálcio (SC) no solo sobre a resistência da soja à FAS. A solução de PS foi pulverizada nas folhas 24 horas antes da inoculação, enquanto que o SC foi aplicado no solo 35 dias antes da semeadura. 0 processo infeccioso de $P$. pachyrhizi foi investigado por microscopia eletrônica de varredura. As urédias nas folhas das plantas pulverizadas com SP foram menores e mais compactas do que as observadas nas folhas das plantas cultivadas em solo contendo SC ou em solo não contendo SC (tratamento controle). Nas folhas das plantas do tratamento controle, as urédias produziram muitos uredosporos aos nove dias após inoculação e a severidade da FAS foi de 15, 8 e 9\% para as plantas dos tratamentos controle, SP e SC, respectivamente. Em conclusão, a pulverização de SP contribuiu para reduzir o número de urédias $\mathrm{cm}^{-2}$ da área foliar e ambas, a pulverização com SP e a aplicação do SC, resultaram na redução dos sintomas da FAS.

Palavras-chave: Glycine max, fungo biotrófico, microscopia eletrônica de varredura. 
The Asian Soybean Rust (ASR), caused by Phakopsora pachyrhizi Syd. \& P. Syd., is one of the most important diseases affecting soybean production worldwide (SINCLAIR and Hartman, 1999). On leaves, the symptoms start as chlorotic polygonal areas limited by the veins, which become necrotic and where uredia containing urediniospores are formed (Reis et al., 2006). Fungal infection on leaves of plants at the pre-flowering or during grain filling growth stages dramatically reduce the number of pods with seeds, number of grains per pod and grain weight due to the intense defoliation (Bromfield, 1984; Hartman et al., 1991; OgLe et al., 1979). The ASR has been managed mainly with fungicides (Miles et al., 2003; ReIs et al., 2006) due to the unavailability of resistant commercial cultivars (Yamanaka et al., 2010). However, the use of silicon (Si), alone or in combination with fungicides, can be an alternative to reduce ASR severity and the extensive use of fungicides, that besides being expensive for the producer are harmful to the environment (Rodrigues et al., 2009).

It has been shown that $\mathrm{Si}$ may have beneficial effects to plants, alleviating biotic and abiotic stresses in crops like barley, cucumber, oat, rice, rye, sugarcane and wheat (DATNOFF et al., 2007). The severity of powdery mildew decreased on cucumber plants supplied with $\mathrm{Si}$ in association with an increase in the activities of defense enzymes (Liang et al., 2005). By contrast, the foliar spray of potassium silicate, as a soluble source of $\mathrm{Si}$, provided satisfactory powdery mildew control without increase the activities of defense enzymes (Liang et al., 2005). According to these authors, the reduction of powdery mildew severity due to the spray of potassium silicate was due to the formation of physical barrier formed after Si deposition on the leaf surface or through an osmotic effect due to the product.

In soybean, Si has been used to control ASR by foliar spraying potassium silicate and by applying calcium silicate to the soil. The spray of potassium silicate solutions with $\mathrm{pH} 10.5$ or 5.5 decreased ASR severity by $36 \%$ and $43 \%$, respectively, compared to plants sprayed with water (Rodrigues et al., 2009). According to Lemes et al. (2011), the onset of rust was delayed by approximately three days and the area under rust progress curve (AURPC) was also significantly lowered in soybean plants grown in soil amended with calcium silicate or sprayed with potassium silicate. In the field, an average 3-days delay in ASR onset was also observed, but only when calcium silicate was amended to the soil. Reductions in the AURPC of up to $43 \%$ and $36 \%$, respectively, were also observed in the field for plants grown in soil amended with calcium silicate or sprayed with potassium silicate (Lemes et al., 2011).

This study was designed to investigate, at the microscopic level, if the spray of potassium silicate and the supply of $\mathrm{Si}$ through soil amendment with calcium silicate could decrease the ASR symptoms.
The soil type used in the experiments was a Sideficient typical Acrustox red-yellow latosol collected at the 'Triângulo Mineiro' savanna area and showed the following characteristics: $530 \mathrm{~g} \mathrm{~kg}^{-1}$ of clay; $\mathrm{pH}$ in $\mathrm{KCl}=4.8$; $\mathrm{P}\left(\right.$ Mehlich-1) $=0.5 \mathrm{mg} \mathrm{dm}^{-3} ; \mathrm{K}$ (Mehlich-1) $=13 \mathrm{mg} \mathrm{dm}^{-3}$; $\mathrm{Al}^{3+}, \mathrm{Ca}^{2+}, \mathrm{Mg}^{2+}, \mathrm{H}^{+}+\mathrm{Al}^{3+}=0.1,0.0,0.0$ and $3.8 \mathrm{cmol}_{c} \mathrm{dm}^{-3}$, respectively; base saturation $=2 \%$ and organic matter $=$ $2.3 \mathrm{dag} \mathrm{kg}^{-1}$. The concentration of available $\mathrm{Si}$ (extraction in $\mathrm{CaCl}_{2}$ ) was $11.8 \mathrm{mg} \mathrm{dm}^{-3}$. Plastic pots (Ecovaso, Jaguariúna, SP, Brazil) were filled with $2 \mathrm{~kg}$ of air-dried, sieved $(5 \mathrm{~mm})$ soil. The calcium silicate used as the Si source (AgroSilício ${ }^{\circledR}$, Harsco Minerais Ltda, Timóteo, Minas Gerais, Brazil) was composed of $10.5 \% \mathrm{Si}, 25 \% \mathrm{Ca}$ and $6 \% \mathrm{Mg}$. The calcium silicate was incorporated into each pot at the rates of 0 and $1.75 \mathrm{~g} \mathrm{~kg}^{-1}$ of soil, which corresponded, respectively, to 0 and $0.39 \mathrm{~g}$ of elemental Si per $\mathrm{kg}$ of soil. Calcium carbonate (40\% Ca, Sigma-Aldrich, São Paulo) and magnesium carbonate $\left(\mathrm{MgCO}_{3}\right.$, Sigma-Aldrich, São Paulo) were added at the rates of 1.19 and $0.48 \mathrm{~g} \mathrm{~kg}^{-1}$ of soil, respectively, to the pots that did not receive $\mathrm{Si}$ in order to equilibrate the amounts of $\mathrm{Ca}$ and $\mathrm{Mg}$ in this treatment with the amounts present in the pots that received $1.75 \mathrm{~g}$ of calcium silicate. The amounts of $\mathrm{Ca}$ and $\mathrm{Mg}$ among the treatments were fixed at 0.27 and $0.05 \mathrm{~g}$, respectively, per pot. The soil in each pot was incubated for 60 days with an approximate humidity of $65 \%$.

Soybean seeds from cultivar MG/BR 46 (Conquista), susceptible to $P$. pachyrhizi, were surface sterilized in $10 \%$ $(\mathrm{v} / \mathrm{v}) \mathrm{NaOCl}$ for $5 \mathrm{~min}$, rinsed in sterilized water for $3 \mathrm{~min}$ and sowed at the rate of four seeds per pot. Five days after emergence, each pot was thinned to two plants. Soil in each pot was fertilized before sowing with $1.63 \mathrm{~g}$ of calcium phosphate per $\mathrm{kg}$ of soil and with $30 \mathrm{~mL}$ of a nutrient solution containing, in $\mathrm{g} \mathrm{L}^{-1}, 6.4 \mathrm{KCl}, 3.48 \mathrm{~K}_{2} \mathrm{SO}_{4}, 5.01 \mathrm{MgSO}_{4} .7 \mathrm{H}_{2} \mathrm{O}$, $2.03\left(\mathrm{NH}_{2}\right)_{2} \mathrm{CO}, 0.009 \mathrm{NH}_{4} \mathrm{MO}_{7} \mathrm{O}_{24} \cdot 4 \mathrm{H}_{2} \mathrm{O}$, $0.054 \mathrm{H}_{3} \mathrm{BO}_{3}, 0.222 \mathrm{ZnSO}_{4} .7 \mathrm{H}_{2} \mathrm{O}, 0.058 \mathrm{CuSO}_{4} .5 \mathrm{H}_{2} \mathrm{O}$ and $0.137 \mathrm{MnCl}_{2} \cdot 4 \mathrm{H}_{2} \mathrm{O}$. The nutrient solution was applied every week after seedlings emergence. A volume of $15 \mathrm{~mL}$ of a solution containing, in $\mathrm{g} \mathrm{L}^{-1}, 0.27 \mathrm{FeSO}_{4} .7 \mathrm{H}_{2} \mathrm{O}$ and 0.37 EDTA bisodium was also applied after seedlings emergence and repeated weekly.

The following treatments were applied to potted plants (i) spray of deionized water (control) and (ii) spray of potassium silicate (PS) (FertiSil ${ }^{\circledR}$, PQ Corporation, São Paulo, Brazil; $\left.20 \mathrm{~g} \mathrm{~L}^{-1}\right) 24 \mathrm{~h}$ before inoculation with $P$. pachyrhizi. The third treatment consisted of plants grown in soil amended with calcium silicate. Deionized water and the solutions of PS were sprayed on the adaxial and abaxial leaves of each plant until runoff using a VL Airbrush atomizer (Paasche Air-brush Co., Chicago, IL, USA). Gelatin (1\%, w/v) was added to the sterile water to aid conidial adhesion. Each plant received $25 \mathrm{~mL}$ of deionized water and PS solution.

Soybean plants at the growth stage V6 (FeHR and Caviness, 1977) were inoculated with a suspension of 
urediniospores of a monopustular isolate (UFV-DPP 08) of $P$. pachyrhizi at a concentration of $1 \times 10^{5}$ urediniospores $\mathrm{mL}^{-1}$. The isolate was previously multiplied in plants of the cultivar MG/BR 46 (Conquista). After inoculation, the plants remained in a mist chamber (temperature of $24 \pm 2^{\circ} \mathrm{C}$, relative humidity of $90 \pm 5 \%$ and absence of light) for $24 \mathrm{~h}$. After this period, the plants were transferred to a plastic mist growth chamber inside a greenhouse for the duration of the experiments. The temperature inside the plastic mist growth ranged from $28 \pm 2^{\circ} \mathrm{C}$ (day) to $20 \pm 2^{\circ} \mathrm{C}$ (night). The relative humidity was maintained at $92 \pm 3 \%$ using a misting system in which nozzles (model NEB-100; KGF Company, São Paulo, Brazil) sprayed mist every $30 \mathrm{~min}$ above the plant canopy. Relative humidity and temperature were measured with a thermo-hygrograph (TH-508, Impac, Brazil).

Leaf fragments $\left(5 \mathrm{~mm}^{2}\right)$ with symptoms of ASR and signs of $P$. pachyrhizi were collected at 9 days after inoculation (dai) and placed in glass vials, fixed with $2.5 \%$ glutaraldehyde in 0.1 $\mathrm{M}$ sodium cacodylate buffer ( $\mathrm{pH} 7.2)$ and stored at $4^{\circ} \mathrm{C}$. The samples were post-fixed for $2 \mathrm{~h}$ at room temperature with osmium tetroxide $1 \%$ in sodium cacodylate buffer $0.1 \mathrm{M}(\mathrm{pH}$ 7.2). The fragments were washed with the same buffer for four times each of $10 \mathrm{~min}$ and dehydrated in an ethanol series. After dehydration, the fragments were subjected to a critical point dryer using the unit Critical Point Dryer (CPD 020 Model, Bal-Tec, Balzers, Liechtenstein). The fragments were mounted on metal stubs with the aid of an aluminum double-sided tape and coated with colloidal gold in a sputter coater apparatus coupled with a Freezing Drying Unit (FDU010 Model, Bal-Tec, Balzers, Liechtenstein). Some samples had their epidermis removed prior to the metallization process to allow the observation of tissue colonization by $P$. pachyrhizi. The fragments were examined by scanning electron microscope (SEM) (Leo 1430 VP Model, Zeiss, Cambridge, UK) operated at $10 \mathrm{kV}$.

After the experiment, all leaves from each plant, replication and treatment were collected, washed in deionized water, dried for $72 \mathrm{~h}$ at $65^{\circ} \mathrm{C}$ and ground to pass through a 40 mesh screen with a Thomas-Wiley mill to determine the foliar $\mathrm{Si}$ concentration (KORNDÖRFER et al., 2004). The foliar calcium (Ca) concentration was determined by atomic absorption spectrophotometry.

To determine the initial uredia formation, ten lesions on each leaflet of the third and fourth leaves, from the basis to the apex, per plant of each treatment were randomly selected. The lesions were examined with a hand held magnifying glass $(\times 10)$. Disease severity was assessed according to the diagram proposed by Godor et al. (2006) at 9 dai. The experiment was arranged in a completely randomized design with three treatments, five repetitions and repeated once. Data from ASR severity and foliar Si concentration of the two experiments were combined for the statistical analysis after determining the homogeneity of variance (Gomes and GARCIA, 2002). Data were analyzed by analysis of variance (ANOVA) and the treatment mean were compared by
Tukey's test $(\mathrm{p} \leq 0.05)$ using SAS (version 6.12; SAS Institute, Inc., Cary, NC).

The foliar Si concentration for plants grown in soil amended with CS was significantly higher $\left(2.6 \mathrm{dag} \mathrm{kg}^{-1}\right)$ in comparison to the control and PS treatments $(0.5$ and $0.6 \mathrm{dag} \mathrm{kg}^{-1}$, respectively). The ASR severity at 9 dai was $15 \%, 8 \%$ and $9 \%$, respectively, for plants from the control, PS and CS treatments. Observations on the stereomicroscope and also on the SEM showed that on leaves of plants from the control treatment, on average, six well developed uredia per pustule were obtained (Figure 1a-c). Plants grown in soil amended with CS and sprayed with PS presented, on average, three uredia (Figure 1d-i). The uredia found on the leaves of plants sprayed with PS were smaller and more compact (Figure 1d-f) than those observed on the leaves of plants grown in soil amended with CS (Figure 1g-i). On leaves of plants from the control treatment, uredia produced many urediniospores (Figure 1a,b). Fungal hyphal was observed in the spongy parenchyma on leaf tissues of plants from all treatments (Figure 1c,f,i).

The present study brings the evidence that $\mathrm{Si}$ translocation from roots to the leaves of soybean plants grown in soil amended with CS was efficient, even considering that this plant species is not efficient in Si uptake from the soil solution in comparison to rice (DATNOFF et al., 2007), to reduce the symptoms of ASR. Rice resistance to blast, caused by Pyricularia grisea, has been attributed to the deposition of a $\mathrm{Si}$ layer below the cuticle, which prevents or delays pathogen penetration (КIм et al., 2002). Thus, it appears that Si, in addition to functioning as a mechanical barrier which limits pathogen penetration, is also involved in the potentiation of host resistance against fungal infection. The application of PS reduced the severity of ASR and the number of uredia per $\mathrm{cm}^{2}$ of leaf area corroborating with the results obtained by Lemes et al. (2011) and Rodrigues et al. (2009).

The spray of PS caused a reduction in the number of uredia, which were also smaller and more compact than those observed on leaves of plants grown in soil amended with CS. This may be related to the physical protection due Si deposition that may hinder pathogen's penetration, delaying the formation of uredia and the disruption of the epidermis that may help to delay urediniospores dispersal. According to Lemes et al. (2011), the delay in the onset of ASR symptoms on plants amended with CS or sprayed with PS was explained by the production of a cuticular sub-layer rich in Si. In addition, fewer and smaller sized uredia compared to those obtained on leaves from the control treatment may be related to a reduced production of urediniospores. In contrast to the results of this experiment, DuArte et al. (2009) found that in the field, PS rates were not effective in reducing the symptoms of ASR compared with fungicide application. In fact, the efficiency of the use of the PS seems to be closely related to the climatic conditions of the study area and the time of application of 

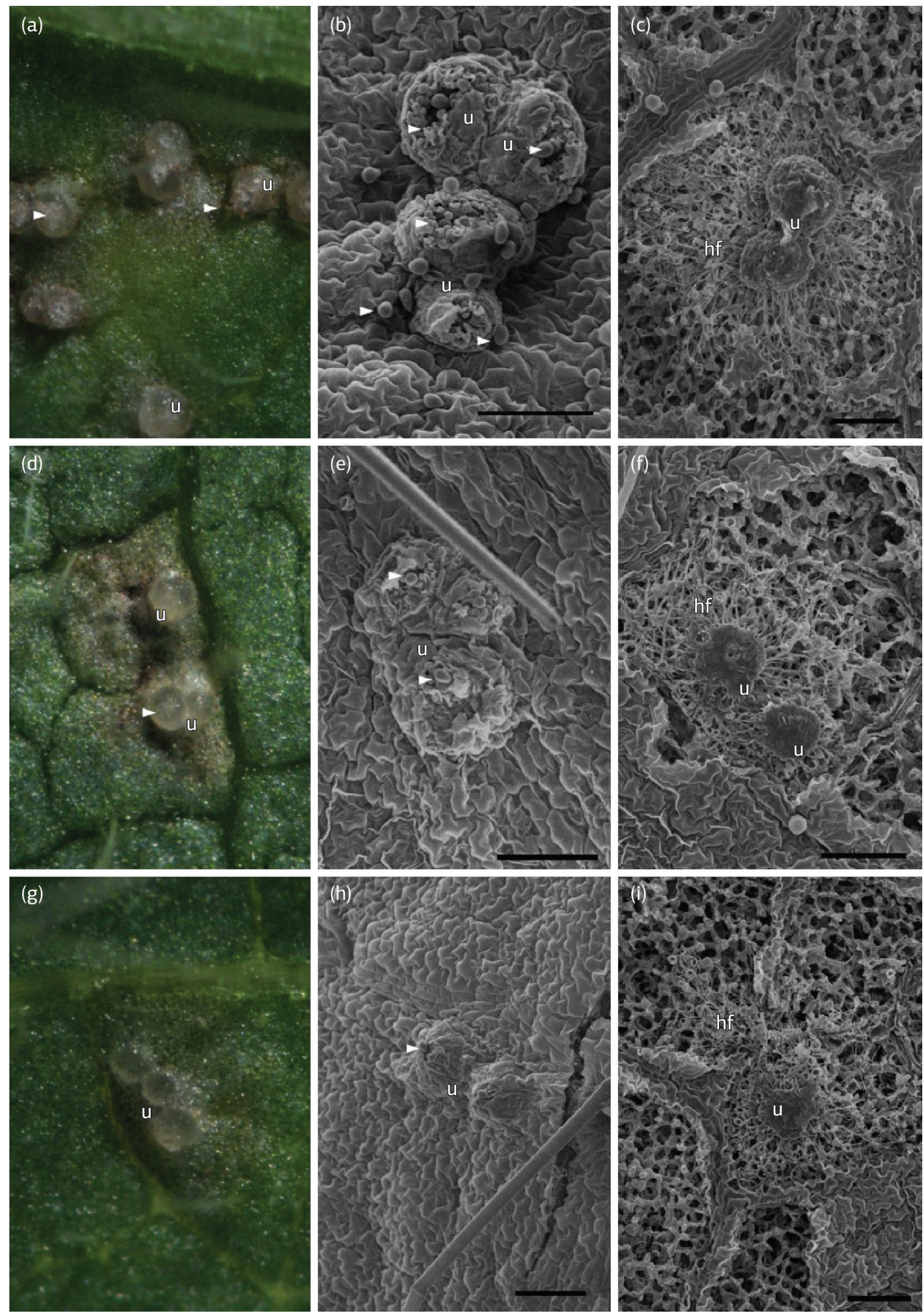

Figure 1. Stereomicroscopy (a, d, g) and scanning electron microscopy (b, c, e, f, h, i) images of leaves of soybean plants sprayed with distilled water (a-c), grown in soil amended with calcium silicate (d-f) and sprayed with potassium silicate (g-i) and inoculated with Phakopsora pachyrhizi. $\mathrm{u}=$ uredia; arrowhead $=$ urediniospores; $\mathrm{hf}=$ fungal hyphae. Bars in $\mathrm{b}, \mathrm{c}, \mathrm{e}, \mathrm{f}, \mathrm{h}$ and $\mathrm{i}=100 \mu \mathrm{m} . \mathrm{a}, \mathrm{d}$ and $\mathrm{g}=100 \times$. 
the product in relation to the quantity and availability of inoculum present in the area.

The results of the present study indicate that the spray of PS led to a one more reduction in the number of uredia per $\mathrm{cm}^{2}$ of leaf area and the symptoms of ARS, in compare to CS. Therefore, the use of foliar spray of PS in combination with adequate cultural practices can contribute to reduce the yield losses caused by severe epidemics of ASR.

\section{ACKNOWLEDGEMENTS}

Profs. FA Rodrigues, MA Moreira and EG Barros thank the CNPq for their fellowships. The authors are grateful to Harsco Minerais Ltda for providing the AgroSilício ${ }^{\circledR}$ and also to the Núcleo de Microscopia e Microanálise (CCB/UFV) for providing the microscopy facilities. This study was supported by CAPES, CNPq, FAPEMIG and FINEP.

\section{REFERENCES}

BROMFIELD, K.R. Soybean rust. St. Paul: American Phytopathological Society, 1984. 63 p. PMCid:PMC241714.

DATNOFF, L.E.; RODRIGUES, F.A.; SEEBOLD, K. Silicon and plant disease. In: DATNOFF, L.E.; ELMER, W.H.; HUBER, D.M. (Eds.). Mineral nutrition and plant disease. St. Paul: The American Phytopathological Society, 2007. p.233-246.

DUARTE, H.S.S.; ZAMBOLIM, L.; RODRIGUES, F.A.; RIOS, J.A.; LOPES, U.P. Silicato de potássio, acibenzolar-S-metil e fungicidas no controle da ferrugem da soja. Ciência Rural, v.39, p.2271-2277, 2009. http://dx.doi.org/10.1590/S0103-84782009000800001

FEHR, W.R.; CAVINESS, C.E. Stages of soybean development. Ames: Iowa State University Press, 1977. 11 p.

GODOY, C.V.; KOGA, L.J.; CANTERI, M.G. Diagrammatic scale for assessment of soybean rust severity. Fitopatologia Brasileira, v.31, p.63-68, 2006. http://dx.doi.org/10.1590/S0100-41582006000100011

GOMES, F.P.; GARCIA, C.H. Análise de grupos de experimentos. In: GOMES, F.P.; GARCIA, C.H. Estatística aplicada a experimentos agronômicos e florestais. Piracicaba: FEALQ, 2002. p.169-191.

HARTMAN, G.L.; WANG, T.C.; TSCHANZ, A.T. Soybean rust development and the quantitative relationship between rust severity and soybean yield. Plant Disease, v.75, p.596-600, 1991. http:// dx.doi.org/10.1094/PD-75-0596

KIM, S.G.; KIM, K.W.; PARK, E.W.; CHOI, D. Silicon-induced cell wall fortification of rice leaves: a possible cellular mechanism of enhanced host resistance to blast. Phytopathology, v.92, p.1095-1103, 2002. PMid:18944220. http://dx.doi.org/10.1094/PHYTO.2002.92.10.1095

KORNDÖRFER, G.H.; PEREIRA, H.S.; NOLLA, A. Análise de silício: solo planta e fertilizante. 2. ed. Uberlândia: Universidade Federal de Uberlândia, 2004. 34 p. (Boletim Técnico, 2).

LEMES, E.M.; MACKOWIAK, C.L.; BLOUNT, A.; MAROIS, J.J.; WRIGHT, D.L.; COELHO, L.; DATNOFF, L.E. Effects of silicon applications on soybean rust development under greenhouse and field conditions. Plant Disease, v.95, p.317-324, 2011. http:// dx.doi.org/10.1094/PDIS-07-10-0500

LIANG, Y.C.; SUN, W.C.; SI, J.; RÖMHELD, V. Effects of foliar and root applied silicon on the enhancement of induced resistance to powdery mildew in Cucumis sativus. Plant Pathology, v.54, p.678685, 2005. http://dx.doi.org/10.1111/j.1365-3059.2005.01246.x

MILES, M.R.; HARTMAN, G.L.; LEVY, C.; MOREL, W. Current status of soybean rust control by fungicides. Pesticide Outlook, v.14, p.197-200, 2003. http://dx.doi.org/10.1039/b311463p

OGLE, H.J.; BYTH, D.E.; McLEAN, R. Effect of rust (Phakopsora pachyrhizi) on soybean yield and quality in south-eastern Queensland. Australian Journal of Agricultural Research, v.30, p.883-893, 1979. http://dx.doi.org/10.1071/AR9790883

REIS, E.M.; BRESOLIN, A.C.R.; CARMONA, M. Doenças da soja I: ferrugem asiática. Passo Fundo: Universidade de Passo Fundo, 2006. 48 p.

RODRIGUES, F.A.; DUARTE, H.S.S.; DOMICIANO, G.P.; SOUZA, C.A.; KORNDÖRFER, G.H.; ZAMBOLIM, L. Foliar application of potassium silicate reduces the intensity of soybean rust. Australasian Plant Pathology, v.38, p.366-372, 2009. http://dx.doi. org/10.1071/AP09010

SINCLAIR, J.B.; HARTMAN, G.L. Soybean rust. In: SINCLAIR, J.B.; BACKMAN, P.A. (Eds.). Compendium of soybean diseases. St. Paul: American Phytopathological Society, 1999. p.25-26.

YAMANAKA, N.; YAMAOKA, Y.; KATO, M.; LEMOS, N.G.; PASSIANOTTO, A.L.L.; SANTOS, J.V.M.; BENITEZ, E.R.; ABDELNOOR, R.V.; SOARES, R.M.; SUENAGA, K. Development of classification criteria for resistance to soybean rust and differences in virulence among Japanese and Brazilian rust population. Tropical Plant Pathology, v.35, p.153-162, 2010. http://dx.doi.org/10.1590/ S1982-56762010000300003 